\title{
A nyugat-nílusi vírus okozta neuroinvazív tünetegyüittes előfordulása sürgősségi osztályon
}

\author{
Koch Márton dr. ${ }^{1}$ - Török Katalin Tímea dr. ${ }^{2}$ \\ Nagy Ferenc dr. ${ }^{2}$ - Soós Viktor ${ }^{1}$ - Pozsgai Éva dr. ${ }^{1,3}$ \\ Lelovics Zsuzsanna dr. - Nagy Anna ${ }^{4}$. Varga Csaba dr. ${ }^{1}$ \\ ${ }^{1}$ Somogy Megyei Kaposi Mór Oktató Kórház, Sürgősségi Betegellátó Centrum, Kaposvár \\ ${ }^{2}$ Somogy Megyei Kaposi Mór Oktató Kórház, Neurológiai Osztály, Kaposvár \\ ${ }^{3}$ Pécsi Tudományegyetem, Általános Orvostudományi Kar, Alapellátási Intézet, Pécs \\ ${ }^{4}$ Nemzeti Népegészségügyi Központ, Virális Zoonózisok Nemzeti Referencia Laboratóriuma, Budapest
}

Bevezetés: Az Európai Betegségmegelőzési és Járványvédelmi Központ adatai szerint a nyugat-nílusi vírus (West Nile virus, WNV) által okozott neuroinvazív tünetegyüttes előfordulása nagymértékben emelkedett Európában és hazánkban az elmúlt években. Ennek hátterében a klíma- és csapadékviszonyok változása valószínúsíthető. A WNV által okozott zoonosist szúnyogok terjesztik. A vírusfertőzés többnyire tünetmentes, $20 \%$-ban általános vírusfertőzéses tüneteket okoz, és kevesebb, mint 1\%-ban halálos kimenetelű neuroinvazív betegséghez vezethet.

Célkitüzés: Közleményünk célja saját eseteinken keresztül a WNV által okozott neuroinvazív tünetegyüttes és az alkalmazott diagnosztikai és terápiás teendők bemutatása, valamint az infekció kapcsán a differenciáldiagnosztikai dilemmák feloldása.

Módszer: A Somogy Megyei Kaposi Mór Kórházban 2018. július 31. és 2018. szeptember 4. között kezelt 4 beteg esetét mutatjuk be, akiknél szerológiai és molekuláris biológiai módszerekkel igazolódott a WNV-fertőzés. A retrospektív esetelemzést a WNV-fertőzés epidemiológiai áttekintésével egészítettük ki.

Eredmények: A jelzett időintervallumban intézményünkben 4 betegnél igazolódott WNV-fertőzés. Minden esetben a neurológiai tünetek széles skáláját észleltük, egy haláleset következett be. A fertőzött betegek idősebbek voltak, valamint számos társbetegségben szenvedtek.

Következtetések: A WNV-fertőzésekre a súlyosabb, neuroinvazív tünetekkel járó kórlefolyás megjelenése jellemző hazánkban is. A fertőzés terápiája szupportív, fájdalomcsillapítást és a szekunder infekciók kezelését foglalja magában. Az ismeretlen etiológiájú neurológiai kórképeknél - különösen encephalitisre utaló tünettan esetén - fontos gondolni a WNV-fertőzésre.

Orv Hetil. 2019; 160(51): 2026-2035.

Kulcsszavak: nyugat-nílusi vírus, virális encephalitis, láz, szúnyogcsípés, sürgősségi ellátás

\section{The occurrence of neuroinvasive symptoms caused by the West Nile virus at an emergency center}

Introduction: According to the European Centre for Disease Prevention and Control, the prevalence of neuroinvasive symptoms caused by the West Nile virus (WNV) has significantly increased in the past years throughout Europe, including Hungary. The rise may be attributed to changes in precipitation and climate. The WNV zoonosis is spread by mosquitoes. It is mostly asymptomatic, flu-like symptoms occur in $20 \%$ of the cases and in less than $1 \%$ a neuroinvasive disease with a lethal outcome may develop.

Aim: Our aim was to demonstrate the neuroinvasive symptomatology and the diagnosis and treatment of WNV infections by describing our patient cases as well as to resolve differential diagnostic dilemmas.

Method: We report the cases of 4 patients treated at the "Moritz Kaposi" Somogy County Hospital between the 31st July and 4th September, 2018, with WNV, whose diagnoses were confirmed by serological and molecular biological methods. An epidemiological overview of WNV infections was also given. 
Results: Four patients were confirmed to have had WNV infection in the given time period. A wide range of neurological symptoms were observed in each patient and death occurred in one case. The patients were elderly with a number of comorbidities.

Conclusions: The appearance of more severe, neuroinvasive symptoms following WNV infections is also characteristic of Hungary. The treatment of the infection is supportive, including giving pain relievers and the management of secondary infections. It is important to consider the possibility of a WNV infection in the case of a neurological disease of unknown origin, particularly if the symptoms indicate encephalitis.

Keywords: West Nile virus, viral encephalitis, fever, mosquitobite, emergency care

Koch M, Török KT, Nagy F, Soós V, Pozsgai É, Lelovics Zs, Nagy A, Varga Cs. [The occurrence of neuroinvasive symptoms caused by the West Nile virus at an emergency center]. Orv Hetil. 2019; 160(51): 2026-2035.

(Beérkezett: 2019. július 11.; elfogadva: 2019. augusztus 27.)

\begin{abstract}
Rövidítések
ÁNTSZ = Állami Népegészségügyi és Tisztiorvosi Szolgálat; $\mathrm{CDC}=($ Centers for Disease Control and Prevention $)$ az Amerikai Egyesült Államok Járványügyi Központja; CRP = C-reaktív protein; $\mathrm{CT}=$ (computed tomography) komputertomográfia; $\mathrm{ECDC}=($ European Centre for Disease Prevention and Control) Európai Betegségmegelőzési és Járványvédelmi Központ; EDTA = etilén-diamin-tetraacetát; EEG = elektroencefalográfia; ELISA = (enzyme-linked immunosorbent assay $)$ enzimhez kapcsolt immunszorbens-vizsgálat; EU = Európai Unió; IFA = (indirect immunofluorescence assay) indirekt immunfluoreszcencia; IgA, - G, $-\mathrm{M}=$ immunglobulin- $\mathrm{A},-\mathrm{G},-\mathrm{M}$; $\mathrm{MR}=$ mágneses rezonancia $;$ NSAID $=$ (non-steroidal anti-inflammatory drugs) nemszteroid gyulladásgátlók; PCR = (polymerase chain reaction) polimeráz-láncreakció; RNS = ribonukleinsav; $\mathrm{WNE}=$ (West Nile encephalitis) nyugat-nílusi encephalitis; WNND $=($ West Nile neuroinvasive disease $)$ nyugat-nílusi neurológiai tünetegyüttes; $\mathrm{WNV}=$ (West Nile virus) nyugat-nílusi vírus
\end{abstract}

Az Európai Betegségmegelőzési és Járványvédelmi Központ adatai szerint a nyugat-nílusi vírus (WNV) által okozott neuroinvazív tünetegyüttes előfordulása több mint hétszeresére nőtt az utóbbi években Európában, így hazánkban is [1]. Ennek hátterében a megváltozott klímaviszonyok közül elsősorban a hőmérséklet emelkedése és a csapadékmennyiség megváltozása állhat, ami más zoonosisokkal együtt - a WNV transzmissziójának kedvez [2].

A betegség gyakoribb előfordulása és potenciális veszélyessége miatt fontos, hogy a kórképet időben felismerjék, és a beteg megfelelő kezelésben részesüljön.

A WNV okozta megbetegedés zoonosis, mely szúnyogvektoron keresztül okoz emberi fertőzést [3]. A kórokozó WNV a flavivírusok közé tartozik, és először 1937-ben izolálták Észak-Ugandában [4]. A WNV hordozói a költöző madarak (reservoir host); a vírust a leggyakrabban a Culex genusba tartozó szúnyogok (vektor) terjesztik. Az ember (illetve más emlősök) a szúnyogok csípése révén fertőződik meg (cyclozoonosis). A vírus a szervezetbe jutás helyén replikálódik, ahonnan a nyirok- csomókba és a véráramba kerül. A vér-agy-gát permeabilitását fokozza, ezáltal direkt módon terjed a központi idegrendszer neuronjaira, különösen a törzsdúcok, az agytörzs, a szürkeállomány és a gerincvelő idegsejtjeire [5]. Emberról emberre természetes úton nem terjed [6], leírtak azonban transzplacentáris vírustranszmissziót [7], illetve transzplantált szerv recipiensének fertőződését is WNV-fertőzött donorszervtól [8], valamint transzfúzió általi transzmissziót is $[9,10]$. Zoonosis lévén a betegség terjedési időszaka a szúnyogok aktív időszakához kötött (nyártól ôszig), a legtöbb fertőzést július és október között dokumentálták [11]. Lovak esetében körülbelül 10\%-ban alakul ki neuroinfekció, embereknél ez az arány sokkal kisebb [3]. A vírussal való fertőződés nem minden esetben vezet betegséghez. Lappangási ideje általában 2-6 nap, de akár több hét is lehet [3]. Nemzetközi irodalmi adatok szerint az emberi fertőzés mintegy $80 \%$-ban aszimptomatikusan zajlik, kb. 20\%-ban okoz általános vírusfertőzésre utaló tüneteket: láz, fejfájás, izom- és ízületi fájdalmak, hányás, hasmenés, bőrkiütések. Becslések szerint minden 150 humánfertőzésből egynél alakul ki neurológiai tünetegyüttes (West Nile neuroinvasive disease, WNND) [12]. Ebben a betegcsoportban a halálozási arány akár $17 \%$ is lehet, ami Görögországban 2010-ben fordult elő 197, WNND-t okozó járvány halálozási rátájaként [13]. Ritkán haemorrhagiás láz klinikai képe is kialakulhat, gyakran fatális kimenetellel. Időskorúaknál a WNND incidenciája sokkal nagyobb: míg az arány 65 év alattiaknál $1: 300$, addig 65 év felettiek esetén $1: 50$ [14].

A WNV-törzseket ma nyolc genetikai vonalba sorolják [15], humán fertőzést - jelenlegi ismereteink alapján - a lineage- 1 és lineage- 2 törzsek okoznak. Az egyes törzsek neuroinvazivitása eltérő [16]. A lineage-1 törzs világszerte elterjedt (Európa, Afrika, Észak-Amerika). A lineage-2-t korábban csak Afrikában találták meg, 2004-ben Európában először Magyarországon izolálták elhullott héjákból [17]. 2007 óta minden évben kimutatható ez a törzs elhullott madarakból, szúnyogokból és tüneteket mutató lovakból [18]. Ennek jelentősége, hogy a korábban apatogénnek tartott lineage- 2 is neuroinvazív tünet- 


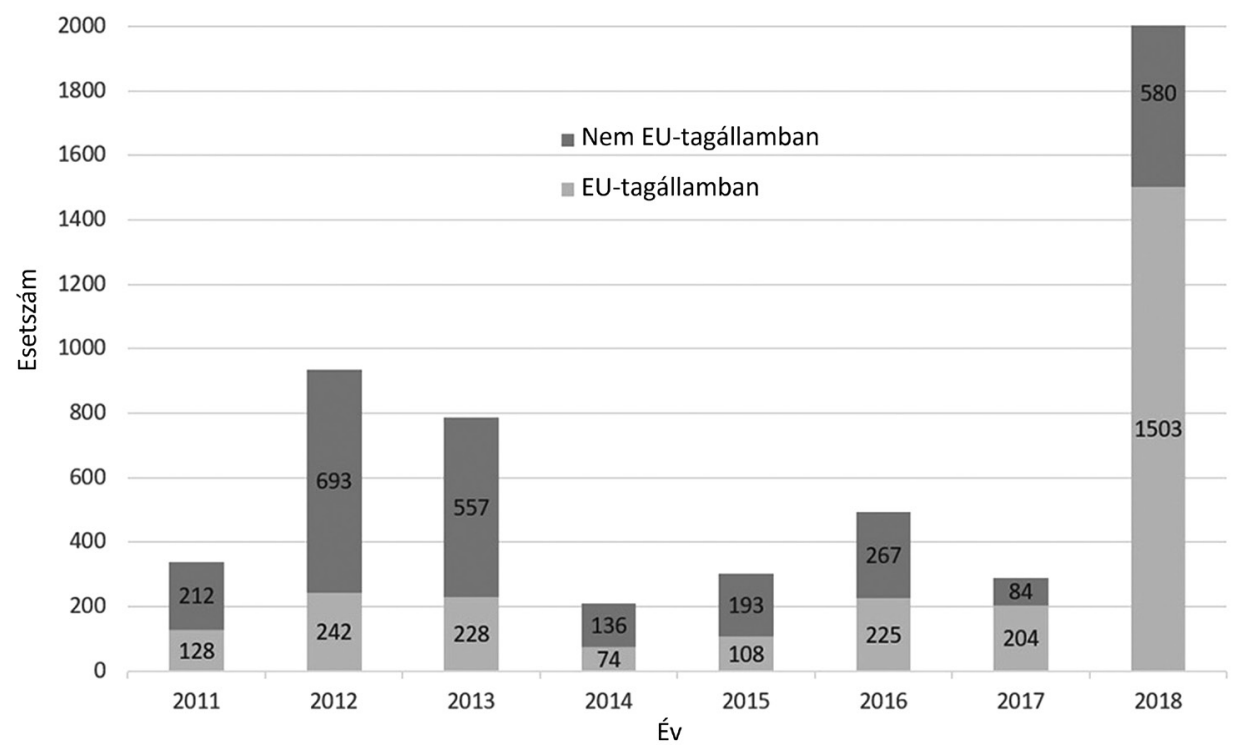

l. ábra $\quad$ WNV okozta humánfertőzések 2011 és 2018 között az ECDC által monitorozott EU-s és EU-n kívüli országokban $\mathrm{EU}=$ Európai Unió; $\mathrm{WNV}=$ nyugat-nílusi vírus

együtteshez vezet [19]. 2008-ban robbanásszerúen nőtt a lineage-2 okozta WNND-k száma madaraknál, lovaknál és embereknél is, Magyarországon és Ausztriában [20].

A 2018. június 25-től 2018. december 13-ig feldolgozott európai járványügyi szervi (European Centre for Disease Prevention and Control [ECDC]) adatok alapján az Európai Unió (EU) országaiban 1503 WNV-fertőzést jelentettek be; a legtöbb fertőzött Olaszországban volt [1]. További 580 megbetegedést igazoltak az EUval határos és az ECDC-statisztikában szereplő országokban (Szerbia, Izrael, Koszovó, Törökország). Magyarországon a Nemzeti Népegészségügyi Központ Járványügyi és Infekciókontroll Főosztálya Járványügyi és Védőoltási Surveillance Osztályának munkatársai öszszegzik és jelentik az ECDC-nek az epidemiológiai adatokat, ez alapján hazánkban 215 autochton esetet rögzítettek [21].

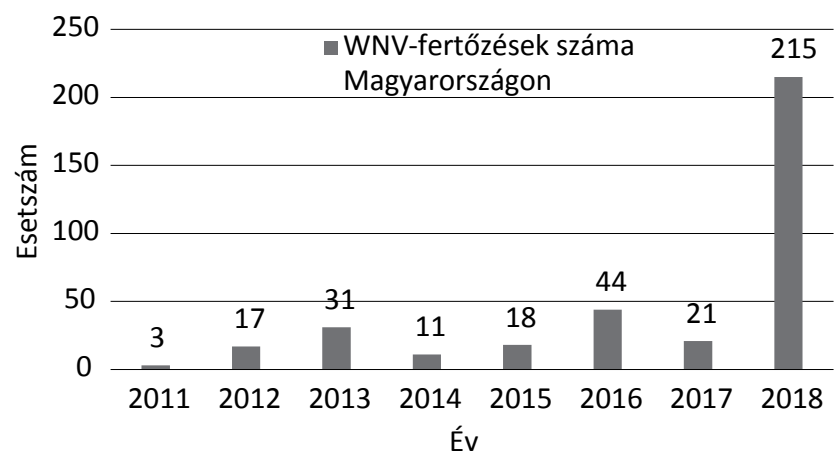

2. ábra

ECDC-statisztikák alapján a magyarországi autochton WNVfertőzések évenkénti előfordulása 2011 és 2018 között

ECDC = Európai Betegségmegelőzési és Járványvédelmi Köz pont; $\mathrm{WNV}$ = nyugat-nílusi vírus
Az említett országokban 2018-ban 180 alkalommal következett be WNV-fertőzéssel kapcsolatos halálozás, ez 8,64\%-os letalitást jelent [22].

Európában a 2018. évben regisztrált fertőzések száma ( $\mathrm{n}=2083$ ) nagymértékben meghaladta a megelőző évek átlagos esetszámát, a 2017-ben regisztrált esetszámhoz képest közel hétszeres emelkedés figyelhető meg (1. ábra). Hazánkra is jellemző volt ez a növekedés: a 2011-2017-es időszak átlagos éves esetszámának $(\mathrm{n}=20,7)$ mintegy a tízszerese volt a 2018-ban rögzített betegszám $(\mathrm{n}=215,2$ ábra $)$.

A 2018-ban identifikált magyarországi humán-WNVfertőzés területi eloszlása a közép- és kelet-magyarországi megyékben mutatott nagymértékű halmozódást (a legnagyobb esetszám Hajdú-Bihar megyében volt, 3. ábra) [22].

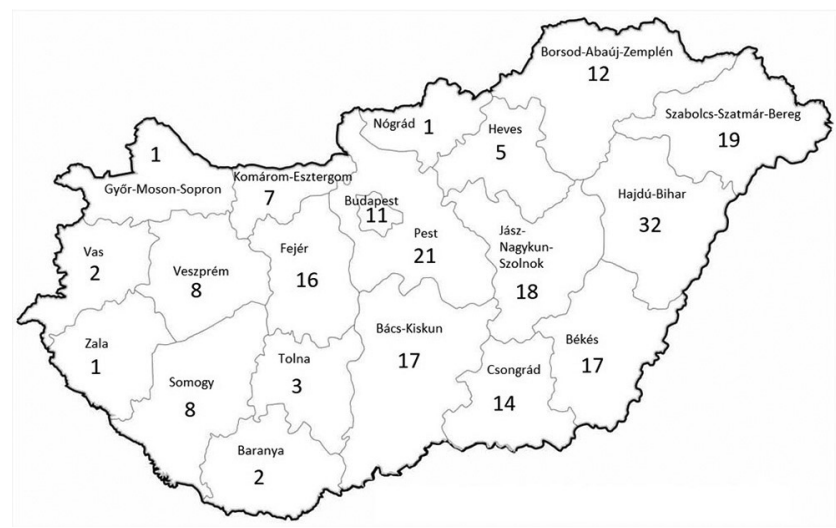

3. ábra

ECDC- és ÁNTSZ-statisztikák alapján 2018-ban Magyarországon igazolt emberi WNV-fertőzések száma megyénként

ÁNTSZ = Állami Népegészségügyi és Tisztiorvosi Szolgálat; ECDC = Európai Betegségmegelőzési és Járványvédelmi Központ; $\mathrm{WNV}=$ nyugat-nílusi vírus 


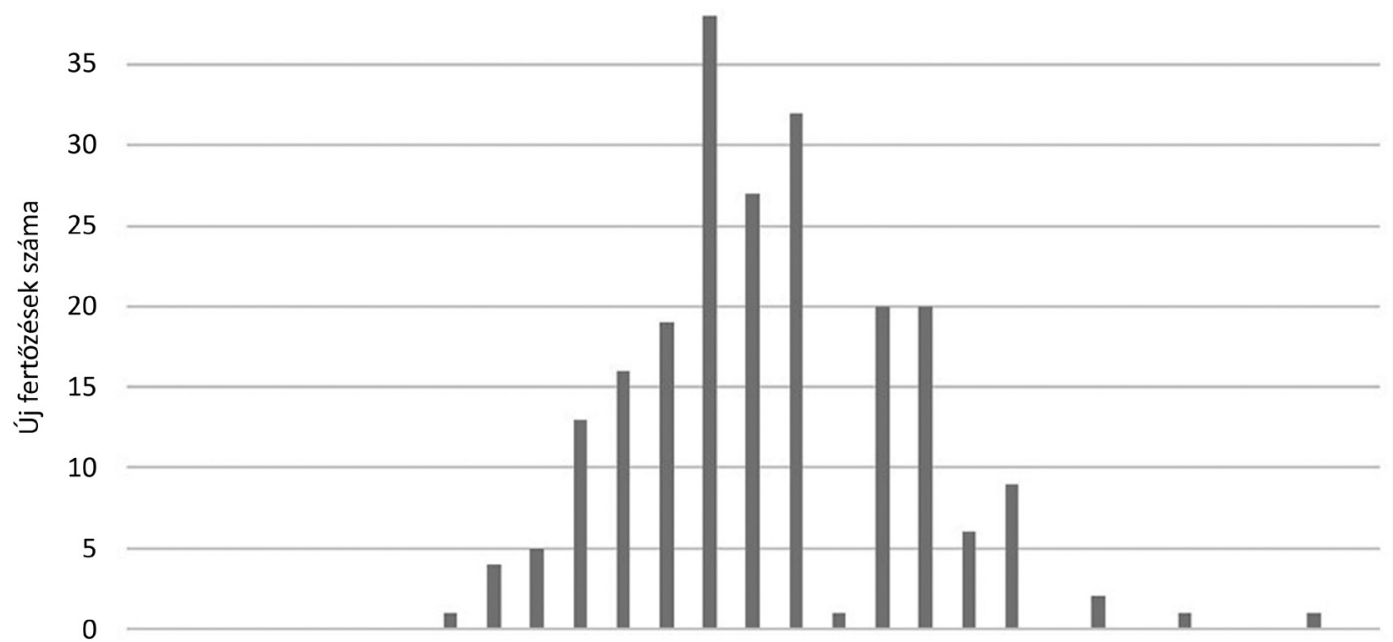

22. 23. 24. 25. 26. 27. 28. 29. 30. 31. 32. 33. 34. 35. 36. 37. 38. 39. 40. 41. 42. 43. 44. 45. 46. 47. 48. 49. 50. Hetek száma

4. ábra

ECDC- és NNK-statisztikák alapján a 2018-ban jelentett emberi WNV-fertőzések idóbeli eloszlása, hetek szerint

NNK = Nemzeti Népegészségügyi Központ; ECDC = Európai Betegségmegelózési és Járványvédelmi Központ; WNV = nyugat-nílusi vírus

A fertőzések időbeli eloszlása megfelelt az európai adatoknak [11]; Magyarországon a legtöbb új fertőzést a 34-40. héten (szeptemberi csúccsal) jelentették, az első infekciót a 29. héten, az évben az utolsót a 49. héten (4. ábra).

A WNV által okozott változatos tünetegyüttes gyakran okoz differenciáldiagnosztikai nehézséget az orvosi ellátás során. A vírus által okozott kórkép prevalenciájának emelkedése miatt viszont elengedhetetlen a betegség felismerése az érintett szakterületeken, beleértve az alap- és sürgősségi, valamint neurológiai és infektológiai ellátást.

Célunk, hogy részletes tudományos irodalmi és epidemiológiai áttekintés tükrében mutassuk be $4 \mathrm{WNV}$-fertőzött beteg esetét, akik 2018 nyarán sürgősségi osztályon jelentkeztek. A betegeken a fertőzéssel járó gyakoribb és ritkább - neuroinvazivitásra utaló - tüneteket egyaránt bemutatjuk, valamint összefoglaljuk az elvégzett diagnosztikus és terápiás lépéseket.

\section{Módszer}

\section{Etikai engedély}

A retrospektív vizsgálat a Somogy Megyei Kaposi Mór Oktató Kórház Intézményi Etikai és Kutatásetikai Bizottságának engedélyével történt (az etikai engedély száma: IG/00759-000/2019).

\section{Esetválasztás}

4, WNV-fertőzés miatt kezelt beteg adatait vizsgáltuk, akiket a Somogy Megyei Kaposi Mór Oktató Kórház Sürgősségi Betegellátó Centrumában és Ideggyógyászati Osztályán kezeltek 2018. július 31. és 2018. szeptember 4. között.

\section{Adatgyüjtés}

Az adatgyújtés a kórházi e-MedSolution informatikai rendszer segítségével történt.

\section{Virusszerológiai és molekuláris biológiai vizsgálatok}

Mintavétel: A vérsavó- és liquorminták szerológiai vizsgálata megtörtént, mind a 4 esetben. Továbbá vizeletminta három, EDTA-val (etilén-diamin-tetraacetát) alvadásgátolt teljes vérminta két betegtôl állt rendelkezésre, melyek PCR (polimeráz-láncreakció)-vizsgálatát szintén elvégeztük. A minták tárolása és szállítása $4{ }^{\circ} \mathrm{C}$-on történt.

A vírusszerológiai és molekuláris biológiai vizsgálatokat a Nemzeti Népegészségügyi Központ Virális Zoonózisok Nemzeti Referencia Laboratóriumában végezték.

\section{Indirekt immunfluoreszcencia (IFA)}

Az indirekt immunfluoreszcens vizsgálat az egyik leggyakrabban használt szerológiai vizsgálómódszer, melynek célja a jelen esetben egy adott vírusra specifikus ellenanyagok kimutatása ( $\operatorname{IgG}, \operatorname{IgM}, \operatorname{IgA})$ volt. A vírusantigén és -ellenanyag kötődése egy fluoreszcens festékkel jelölt, izotípus-specifikus, másodlagos antitest hozzáadásával, majd fluoreszcens mikroszkópos leolvasással tehető láthatóvá. A vérsavó- és liquorminták szerológiai vizsgálata során az IFA-módszer lehetővé tette a különböző izotípusú ellenanyagok kimutatása mellett az ellenanyagvégtiter meghatározását is, aminek a WNV-fertőzések laboratóriumi differenciáldiagnosztikája szempontjából volt jelentősége. A Flavivirus nemzetséghez tartozó vírusok szoros antigénrokonságából adódó szerológiai keresztreakciók miatt a területen endémiás egyéb Flavivi- 
rusok irányában (kullancsencephalitis-vírus, Usutu-vírus) is indokolt volt az ellenanyag-kimutatást elvégezni és pozitív eredmény esetén az ellenanyagtiter-értékeket összehasonlítani.

\section{ELISA (enzyme-linked immunosorbent assay)}

$\mathrm{Az}$ indirekt immunfluoreszcens módszer kiegészítéséül magas szenzitivitású WNV 'capture' IgM ELISA-vizsgálatokra is sor került a vérsavómintákból (West Nile Virus IgM Capture DxSelect, Focus Diagnostics, DiaSorin Molecular LLC, Cypress, CA, USA).

\section{Molekuláris biológiai módszerek (PCR)}

A szerológiai vizsgálatokat molekuláris diagnosztikai módszerekkel egészítettük ki. A PCR-vizsgálathoz a leginkább alkalmas mintatípusok, melyekból a legnagyobb valószínúséggel mutatható ki a virális nukleinsav: az EDTA-val alvadásgátolt teljes vér, valamint vizeletminták [23-26]. A vér- és vizeletminták PCR-vizsgálata a WNVgenom konzervatív [27] szakaszának felsokszorosítására alkalmas, hidrolízispróbás 'real-time' (valós idejü) PCRmódszerrel történt, mely lehetôvé tette mind a lineage-1, mind pedig a lineage- 2 vírustörzsek gyors kimutatását. A WNV-PCR mellett a laboratórium protokollja szerint Usutu-vírus-specifikus PCR-vizsgálatra [28] is sor került (4. táblázat). Mivel az Usutu-vírus és a WNV ugyanazon Flavivirus-antigén-komplex - japán encephalitisvírus-szerokomplex [29] - tagjai, szerológiai alapon történő elkülönítésük nehézségekbe ütközhet. Ezért javasolt e két vírus esetén a szerológiai diagnosztikai módszerek mellett a párhuzamosan történő víruskimutatás elvégzése is. A 'real-time' PCR alapján pozitív minták konfirmáló vizsgálata 'nested' (fészkes) PCR-módszerrel történt, a virális genom egy variábilisabb szakaszának felsokszorosításával [30]. A 'nested' PCR-módszer két primerpár felhasználásával, egy tulajdonképpeni biamplifikáció révén nagy érzékenységgel teszi lehetővé a vírusnukleinsav kimutatását. Emellett a 'nested' PCR-termékek felhasználhatók nukleotidsorrend-meghatározáshoz is, azaz a Sanger-féle didezoximódszeren alapuló szekvenáláshoz, mely a vírustörzs azonosításához nélkülözhetetlen. A szekvenciaadatok génbanki adatbázisba (https://www.ncbi.nlm.nih.gov/genbank/) történő feltöltése mellett a WNV-lineage-meghatározás eredménye az ECDC számára is jelentésre került.

\section{A WNV-fertózés laboratóriumi esetminösitésének kritériumai}

A laboratóriumi eredmények értékelése az Európai Unió Bizottsága által elfogadott, a közösségi hálózatnak jelentendő fertőző betegségek esetdefinícióinak meghatározásáról szóló határozata alapján történt [31]. E szerint a megerősíthető WNV-fertőzés laboratóriumi kritériuma az alábbi négy feltétel legalább egyikének teljesülése:

- a WNV izolálása vérből vagy liquormintából;

- a WNV-nukleinsav kimutatása vérből vagy liquormintából;

- WNV-specifikus IgM-ellenanyagok kimutatása liquormintából;

- WNV-specifikus IgM-ellenanyagok kimutatása vérból magas titerben, IgG típusú ellenanyagok mellett, és a kapott eredmények megerősítése vírusneutralizációs próbával.

Amennyiben nyugat-nílusi vírussal szembeni ellenanyag-kimutatás történik egyetlen vérsavómintából, valószínűsíthető esetminősítés adható.

A mikrobiológiai véleményezés a Flavivirus-oltási status és az esetleges utazási anamnézis figyelembevételével, valamint a területen előforduló egyéb Flavivirusok által okozott infekció kizárásával történt.

\section{Eredmények}

A Somogy Megyei Kaposi Mór Oktató Kórházban a jelzett időintervallum alatt a szerológiai vizsgálatok 4 betegnél igazoltak WNV-fertózést. A egyes esetek betegséglefolyása nagyon eltérő volt, tüneteik változatosak voltak, amit belgyógyászati komorbid állapotok is komplikáltak.

\section{A WNV-fertözött betegek tünettanának, diagnosztikus és terápiás lépéseinek áttekintése}

\section{A sürgősségi osztályon történt események}

A sürgősségi ambulancián 3 férfi és 1 nóbeteg jelentkezett. Anamnézisükben különböző belgyógyászati társ- és kísérő betegségek szerepeltek (1. táblázat).

Valamennyi betegnél a hospitalizációt megelőző egy héten belül igazolható volt lázas állapot, egyikük a felvételkor is lázas volt $\left(\mathrm{T}=38,6^{\circ} \mathrm{C}\right)$. Gastrointestinalis tünetek (hányinger, hányás, vizes hasmenés, alhasi fájdalom) két esetben fordultak elő, bőrkiütés egy alkalommal. Objektivizálható neurológiai eltérés igazolódott minden esetben: valamennyi páciensnél jellemző panasz volt az egyensúlyzavar. Ataxia és paresis 3 páciensnél, nystagmus 2-nél, 1-1 betegnél pedig diplopia és enyhe szenzoros aphasia került dokumentálásra (1. táblázat).

A laborvizsgálatok típusos eltérést nem igazoltak, a gyulladásos markerek (fehérvérsejtszám, C-reaktív protein $[\mathrm{CRP}])$ emelkedése három esetben fordult elő.

A szerteágazó neurológiai tünetegyüttes miatt minden betegnél megtörtént a natív koponya-CT-vizsgálat, melyek a radiológiai szakvélemény alapján negatív eredményüek voltak. Egy alkalommal a számítógépes szoftveres score-analízis (Alberta Stroke Program Early CT score, e-ASPECTS) [32] bal oldali arteria cerebri media területi friss ischaemia lehetőségét vetette fel. 
1. táblázat |A kórházunkban WNV-fertőzés miatt kezelt betegek sürgősségi ambulanciánkon történt vizsgálatai, diszpozíciója

\begin{tabular}{|c|c|c|c|c|c|c|}
\hline Kor és nem & Alapbetegségek & Tünetek, panaszok & Neurológiai tünetek & $\begin{array}{l}\text { Kóros laboratóriumi } \\
\text { értékek }\end{array}$ & Koponya-CT & Diszpozíció \\
\hline 61 éves nő & Hypertonia & $\begin{array}{l}\text { Láz, egyensúlyzavar, } \\
\text { hányás, hasmenés, } \\
\text { bőrkiütés, kettős látás, } \\
\text { fejfájás, hasi fájdalom }\end{array}$ & $\begin{array}{l}\text { Ataxia, nystagmus, } \\
\text { diplopia }\end{array}$ & Kórjelző nélkül & Negatív & Stroke Részleg \\
\hline 59 éves férfi & $\begin{array}{l}\text { Hypertonia, diabetes } \\
\text { mellitus }\end{array}$ & $\begin{array}{l}\text { Láz, egyensúlyzavar, } \\
\text { izomfájdalom }\end{array}$ & Ataxia, paraparesis & $\begin{array}{l}\text { FVS } 10,3 \mathrm{G} / 1(\uparrow) \\
\text { CK } 658 \mathrm{U} / 1(\uparrow) \\
\text { GOT } 60 \mathrm{U} / 1(\uparrow) \\
\text { GPT } 110 \mathrm{U} / 1(\uparrow)\end{array}$ & Negatív & Stroke Részleg \\
\hline 76 éves férfi & $\begin{array}{l}\text { Hypertonia, pitvari } \\
\text { fibrilláció, aortasteno- } \\
\text { sis, pangásos szívelég- } \\
\text { telenség }\end{array}$ & $\begin{array}{l}\text { Láz, egyensúlyzavar, } \\
\text { egyoldali végtaggyen- } \\
\text { geség, cardialis } \\
\text { dekompenzáció }\end{array}$ & Ataxia, hemiparesis & $\begin{array}{l}\mathrm{CRP} 10 \mathrm{mg} / \mathrm{l}(\uparrow) \\
\text { GOT } 64 \mathrm{U} / 1(\uparrow) \\
\mathrm{LDH} 609 \mathrm{U} / \mathrm{l}(\uparrow)\end{array}$ & $\begin{array}{l}\text { Negatív } \\
\text { (e-ASPECTS } \\
\text { score: } 8 \text { ) }\end{array}$ & $\begin{array}{l}\text { Kardiológiai } \\
\text { Osztály }\end{array}$ \\
\hline 61 éves férfi & $\begin{array}{l}\text { Hypertonia, diabetes } \\
\text { mellitus, ischaemiás } \\
\text { szívbetegség, } \\
\text { májcirrhosis }\end{array}$ & $\begin{array}{l}\text { Láz, egyensúlyzavar, } \\
\text { hányás, hasmenés, } \\
\text { látászavar, beszédzavar }\end{array}$ & $\begin{array}{l}\text { Nystagmus, paresis, } \\
\text { aphasia }\end{array}$ & $\begin{array}{l}\text { FVS } 12,3 \mathrm{G} / 1(\uparrow) \\
\text { CK } 773 \mathrm{U} / 1(\uparrow) \\
\text { TCT } 55 \mathrm{G} / \mathrm{l}(\downarrow) \\
\mathrm{Na} 128 \mathrm{mmol} / \mathrm{l}(\downarrow)\end{array}$ & Negatív & Stroke Részleg \\
\hline
\end{tabular}

ASPECTS $=$ Alberta Stroke Program Early CT score; CK = kreatin-kináz; CRP = C-reaktív protein; $\mathrm{CT}=$ komputertomográfia; FVS = fehérvérsejt; GOT = glutamát-oxálacetát-transzamináz; GPT = glutamát-piruvát-transzamináz; LDH = laktát-dehidrogenáz; TCT = thrombocyta; WNV = nyugat-nílusi vírus

1 betegünket szívelégtelenség domináló tünetei miatt a Kardiológiai Osztályra helyeztünk először, aki neurológiai statusának progressziója (jobb oldali hemiparesis, aphasia) miatt 24 óra múlva a másik 3 beteghez hasonlóan a Neurológiai Osztályra került áthelyezésre.

\section{A Neurológiai Osztályon/Stroke Részlegen történt események}

A koponya-MR-vizsgálat mellett l betegnél a paraparesis miatt teljes gerinc-MR-felvétel készült, mely conusmyelitist igazolt. Lumbálpunkción 3 páciens esett át, amelyek eredménye mindegyiknél lymphocytás meningitisre utalt, egy alkalommal véralvadási zavar (thrombocytopenia, $47 \mathrm{G} / \mathrm{l}$ ) miatt nem történt mintavétel (2. táblázat).
Az elkészült szerológiai vizsgálatok WNV-fertőzést jeleztek. A vírus RNS-e egy mintából volt kimutatható, a nukleinsav-meghatározás alapján a fertőzést a lineage-2 törzs okozta. Egy esetben a mikrobiológiai laboratóriumi vizsgálatok eredménye a beteg emisszióját követően, kontrollvizsgálat során igazolta az akut vagy közelmúltban lezajlott fertőzést, l betegnél post mortem igazolódott a WNV-fertózés (3. táblázat).

Encephalitisre, illetve myelitisre utaló klinikai kép három esetben alakult ki, egy esetben encephalopathia és cerebelláris tünetek jelentkeztek. A liquor mikroszkópos vizsgálatát követően virális fertőzésnek megfelelő empirikus kezelés történt. A purulens agyhártyagyulladást meningitisgyorsteszttel (agglutinációs teszt), két esetben a Patológiai Osztályon részletes citológiai vizsgálattal,

2. táblázat |A kórházunkban WNV-fertőzés miatt kezelt betegeknek a Neurológiai Osztályon, a Stroke Részlegen történt vizsgálatai, terápiája és utánkövetése

\begin{tabular}{|c|c|c|c|c|c|c|}
\hline Kor és nem & MR & Liquor & Szerológia & Klinikai kép & Terápia & Utánkövetés \\
\hline 61 éves nő & $\begin{array}{l}\text { Koponya-MR } \\
+ \text {-MRA } \\
\text { negatív }\end{array}$ & $\begin{array}{l}\text { - Mikroszkópia: lymphocyták } \\
\text { - Gyorsteszt: negatív } \\
\text { - Citológia: lymphocyták }\end{array}$ & $\begin{array}{l}\text { Pozitív } \\
\text { liquor és } \\
\text { szérum }\end{array}$ & Encephalitis & NSAID & $\begin{array}{l}\text { Infektológiai Osztályra } \\
\text { helyezés, szupportív } \\
\text { kezelés, emisszió } \\
\text { panaszmentesen }\end{array}$ \\
\hline 59 éves férfi & $\begin{array}{l}\text { Gerinc-MR: } \\
\text { conusmyelitis }\end{array}$ & $\begin{array}{l}\text { - Mikroszkópia: lymphocyták } \\
\text { - Citológia: lymphocyták } \\
\text { - Tenyésztés: negatív }\end{array}$ & $\begin{array}{l}\text { Pozitív } \\
\text { liquor és } \\
\text { szérum }\end{array}$ & $\begin{array}{l}\text { Conus-, epiconus- } \\
\text { myelitis }\end{array}$ & $\begin{array}{l}\text { Szteroid, } \\
\text { plazmaferézis }\end{array}$ & $\begin{array}{l}\text { Mozgásszervi } \\
\text { Rehabilitációs } \\
\text { Osztályra helyezés }\end{array}$ \\
\hline 76 éves férfi & - & $\begin{array}{l}\text { - Mikroszkópia: lymphocyták } \\
\text { - Gyorsteszt: negatív }\end{array}$ & $\begin{array}{l}\text { Pozitív } \\
\text { liquor és } \\
\text { szérum }\end{array}$ & $\begin{array}{l}\text { Szívelégtelenség, } \\
\text { hemiparesis, aphasia, } \\
\text { encephalitis }\end{array}$ & $\begin{array}{l}\text { Diuretikum, } \\
\text { antibiotikum, } \\
\text { antivirális szer }\end{array}$ & Exitus \\
\hline 61 éves férfi & $\begin{array}{l}\text { Koponya-MR } \\
+ \text {-MRA } \\
\text { negatív }\end{array}$ & $\begin{array}{l}\text { Thrombocytopenia miatt nem } \\
\text { történt mintavétel }\end{array}$ & $\begin{array}{l}\text { Pozitív } \\
\text { szérum }\end{array}$ & $\begin{array}{l}\text { Cerebelláris tünetek, } \\
\text { encephalopathia }\end{array}$ & $\begin{array}{l}\text { Belgyógyászati } \\
\text { alapbetegségek } \\
\text { kezelése }\end{array}$ & $\begin{array}{l}\text { A WNE diagnózisa } \\
\text { már járó betegként, } \\
\text { állapota javult }\end{array}$ \\
\hline
\end{tabular}

$\mathrm{MR}=$ mágneses rezonancia MRA = mágneses rezonanciás angiográfia; NSAID = nemszteroid gyulladásgátlók; WNE = nyugat-nílusi encephalitis; $\mathrm{WNV}=$ nyugat-nílusi vírus 
3. táblázat |A nyugat-nílusi, az Usutu- és a kullancsencephalitis-vírus elleni ellenanyag-vizsgálatok eredményei, indirekt immunfluoreszcens módszerrel

\begin{tabular}{|c|c|c|c|c|c|c|c|c|c|}
\hline Kor és nem & Minta, a mintavétel időpontja & WNV-IgG & WNV-IgM & WNV-IgA & USUV-IgG & USUV-IgM & USUV-IgA & KEV-IgG & KEV-IgM \\
\hline \multirow[t]{3}{*}{61 éves nő } & 1. vérsavó (2018. 08. 01.) & $1: 640$ & Pozitív & Pozitív & $1: 40$ & Negatív & Negatív & $1: 80$ & Negatív \\
\hline & 2. vérsavó (2018. 08. 06.) & $1: 640$ & Pozitív & Pozitív & $1: 40$ & Negatív & Nem vizsg. & $1: 80$ & Nem vizsg. \\
\hline & Liquor (2018. 08. 01.) & Pozitív & Pozitív & Pozitív & Pozitív & Negatív & Negatív & Pozitív & Negatív \\
\hline \multirow{4}{*}{$\begin{array}{l}59 \text { éves } \\
\text { férfi }\end{array}$} & 1. vérsavó (2018. 08. 22.) & $1: 160$ & Pozitív & Pozitív & $1: 80$ & Negatív & Negatív & $1: 10$ & Negatív \\
\hline & 2. vérsavó (2018. 09. 03.) & $1: 160$ & Pozitív & Pozitív & $1: 80$ & Nem vizsg. & Nem vizsg. & $1: 10$ & Nem vizsg. \\
\hline & 3. vérsavó (2018. 11. 05.) & $1: 640$ & Negatív & Negatív & $1: 80$ & Negatív & Negatív & $1: 10$ & Negatív \\
\hline & Liquor (2018. 08. 22.) & Pozitív & Pozitív & Pozitív & Negatív & Negatív & Nem vizsg. & Pozitív & Negatív \\
\hline \multirow{2}{*}{$\begin{array}{l}76 \text { éves } \\
\text { férfi }\end{array}$} & Vérsavó (2018. 08. 28.) & $1: 1280$ & $\geq 1: 320$ & $\geq 1: 320$ & $1: 320$ & $\geq 1: 320$ & $1: 80$ & $1: 10$ & Negatív \\
\hline & Liquor (2018. 08. 28.) & Pozitív & Pozitív & Pozitív & Pozitív & $\begin{array}{l}\text { Gyengén } \\
\text { pozitív }\end{array}$ & $\begin{array}{l}\text { Gyengén } \\
\text { pozitív }\end{array}$ & $\begin{array}{l}\text { Gyengén } \\
\text { pozitív }\end{array}$ & Negatív \\
\hline \multirow{2}{*}{$\begin{array}{l}61 \text { éves } \\
\text { férfi }\end{array}$} & 1. vérsavó (2018. 08. 09.) & $1: 320$ & Pozitív & Pozitív & $1: 40$ & Negatív & Negatív & Negatív & Nem vizsg. \\
\hline & 2. vérsavó (2018. 08. 29.) & $1: 1280$ & Pozitív & Pozitív & $1: 320$ & Negatív & Negatív & Nem vizsg & Nem vizsg. \\
\hline
\end{tabular}

$\mathrm{IgA},-\mathrm{G},-\mathrm{M}$ = immunglobulin-A, -G, -M; KEV = kullancsencephalitis-vírus; USUV = Usutu-vírus; WNV = nyugat-nílusi vírus

a myelitis diagnózisa esetében tenyésztéses vizsgálattal sikerült kizárni a bakteriális eredetet (2. táblázat).

WNV-fertőzéssel kapcsolatos halálozás egy esetben történt, amelyben valószínúleg a beteg idősebb kora mellett súlyos társbetegségei (szívelégtelenség; szignifikáns, súlyos aortastenosis, melyet korábban komorbitidások miatt inoperábilisnak minősítettek) is közrejátszottak. A beteg ápolásának második napján magas láz $\left(\mathrm{T}_{\max }=39,7^{\circ} \mathrm{C}\right)$ alakult ki, neurológiai tünetei (jobb oldali hemiparesis, aphasia) progrediáltak, mélyülő tudatzavar lépett fel, az EEG-n epilepsziás funkciózavar igazolódott, a fehérvérsejtszám 15,78 G/l-re, a CRP $126,1 \mathrm{mg} / \mathrm{l}$-re emelkedett. A góckutatás lymphocytás meningoencephalitist igazolt, egyéb fertőzésforrás nem volt identifikálható. Empirikusan széles spektrumú antibiotikumkezelésben (ceftriaxon $2 \times 1 \mathrm{~g}$ ) és aciklovirterápiában részesült. A kórházi MET- (medical emergency team) rendszer bevonása, valamint a cardiopulmonalis támogatás ellenére tünetei progrediáltak, exitált. Az elhunyt kórboncolása nem történt meg.

\section{Jellemző („klasszikus”) tünetekkel járó eset bemutatása}

A hatvanéves, hypertoniában szenvedô nőbeteg 2018. július végén a lakhelyéhez közeli kórház sürgősségi ambulanciáján egyhetes panaszokkal jelentkezett. Hasmenéssel, alhasi fájdalommal, fejfájással kezdődött a betegsége. Három-négy napig mellkasán és karján exanthemák jelentek meg, esténként belázasodott, hidegrázása volt. Hasmenése, hasi fájdalma, kiütései néhány nap alatt megszúntek, azonban gyengesége, egyensúlyzavara lépett fel. Ekkor utalták kórházunkba, agytörzsi stroke gyanúja miatt. Az első laborvizsgálatok kórjelzőt nem mutattak. Az ambulanciánkon készült natív koponyaCT-vizsgálata érdemi eltérést nem igazolt. Az észlelt nystagmus ('square wave jerks', horizontális és vertikális) és törzsataxia miatt a neurológus stroke-protokoll szerint MR-vizsgálatát, majd a Stroke Részlegre történő felvételét indikálta. A mágneses rezonanciás angiográfia (MRA) nem írt le a panaszait magyarázó kóros eltérést. Tekintettel anamnézisére, lumbálpunkció történt, melynek során makroszkóposan tiszta liquor ürült; a Pándyteszt pozitív volt, a mikroszkópos vizsgálat látóterenként 206/3 lymphocytát, 30/3 granulocytát igazolt. A meningitis agglutinációs gyorsteszt negatív volt; a Patológiai Osztályon részletes citológiai vizsgálat is történt a liquorból, amely a serosus meningitis diagnózisát erősítette meg. A beteg - a felvételtôl számított 24 órán belül - az Infektológiai Osztályra került. (Áthelyezést követően serosus meningitisnek megfelelő szupportív kezelés történt, nemszteroid gyulladásgátlók [NSAID, dexibuprofén, diklofenák] per os, mannitolinfúzió intravénás adása). Az elkészült liquor szerológiai vizsgálatok WNVfertőzést jeleztek. Az anti-WNV-kimutatás IgA, IgG és IgM saját antigénnel, immunfluoreszcenciás módszerrel

\begin{tabular}{|c|c|c|c|}
\hline \multirow{2}{*}{$\begin{array}{l}\text { 4. táblázat } \\
\text { Kor és nem }\end{array}$} & \multicolumn{3}{|c|}{$\begin{array}{l}\text { Az alvadásgátolt teljesvér- és vizeletmintákon végzett nyugat-ní- } \\
\text { lusi és Usutu-vírus-specifikus PCR-vizsgálatok eredményei }\end{array}$} \\
\hline & Minta, a mintavétel időpontja & WNV-PCR & USUV-PCR \\
\hline \multirow[t]{2}{*}{61 éves nő } & $\begin{array}{l}\text { Alvadásgátolt vér } \\
(2018.08 .06 .)\end{array}$ & Negatív & Negatív \\
\hline & Vizelet (2018.08.06.) & Negatív & Negatív \\
\hline 59 éves férfi & $\begin{array}{l}\text { Nem történt a vizsgálathoz } \\
\text { megfelelő minta küldése }\end{array}$ & & \\
\hline \multirow[t]{2}{*}{76 éves férfi } & $\begin{array}{l}\text { Alvadásgátolt vér } \\
(2018.08 .28 .)\end{array}$ & $\begin{array}{l}\text { Pozitív, } \\
\text { lineage-2 }\end{array}$ & Negatív \\
\hline & Vizelet (2018. 08. 28.) & $\begin{array}{l}\text { Pozitív, } \\
\text { lineage-2 }\end{array}$ & Negatív \\
\hline 61 éves férfi & Vizelet (2018.08.09.) & Negatív & Negatív \\
\hline
\end{tabular}

PCR = polimeráz-láncreakció; USUV = Usutu-vírus; $\mathrm{WNV}=$ nyugat nílusi vírus 
pozitív volt. A mintából a vírus-RNS nem volt kimutatható PCR-technikával. Az ápolás során a páciens panaszai fokozatosan csökkentek, láza nem ismétlődött, más infekciós tünete sem volt, novum neurológiai eltérés nem alakult ki. Háromhetes kezelést követően panaszmentesen hagyta el a kórházat, maradványtünet nélkül.

\section{Megbeszélés}

A WNV-fertőzések epidemiológiájára a növekvő prevalencia, valamint a súlyosabb, neuroinvazív tünetekkel járó kórlefolyás megjelenése jellemző. Az 1960-as évek elején már Európában, Franciaországban is dokumentáltak meningoencephalitisszel járó WNV-infekciót, a fertőzöttek nagy részénél azonban enyhe lefolyású, lázas megbetegedés zajlott csupán, idegrendszeri érintettséget ritkán okozott [33]. Bukarestben és a Duna árterületén az 1996. júliustól októberig tartó járványban figyelték meg [34], hogy a vírus epidemiológiai és az okozott tünetegyüttes klinikai jellemzői is változáson mentek át. Ez volt az első dokumentált WNV-járvány, amely döntően városi környezetben alakult ki, valamint jelentős számú központi idegrendszeri tünetegyüttest is okozott [35].

1999 nyarán New Yorkban is megjelent a WNV súlyos tünetekkel, a nyugati féltekén elsőként. Az ezt követő években lassú terjedést mutatott a régióban, míg 2002 nyarán a valaha leírt legtöbb áldozatot követelö WNVjárvány pusztított Észak-Amerikában, 4156 fertőzöttel, 2354 esetben meningoencephalitist okozva, melyből 284 halálos kimenetellel végződött [36].

2012-ben Észak-Olaszországban 25 WNND-t dokumentáltak; az országos szűrőprogramnak köszönhetően 14 véradó donort is identifikáltak, WNV-hordozóként. Korábbi epidémiákhoz viszonyítva a központi idegrendszert érintő szövődmények száma kiugróan nagy volt [37]. A járvány ideje alatt 2 , WNND-hez köthető halálozást jelentettek. Olaszországban 2010 óta minden évben július 15-től november 30-ig országos szintű WNVszúrőprogram müködik, melynek során rögzítik a lehetséges, valószínű és biztos WNV-fertőzéseket, illetve szürik a véradó- és szervdonorokat is a vírusra [38]. Az ECDC statisztikáit áttekintve 2018-ban a WNV-fertőzések korábban kezdődtek, valamint az esetszám is szignifikánsan nagyobb volt az elmúlt évekhez képest [1].

Bemutatott eseteink jól példázzák, hogy a WNV okozta fertőzés tünettana igen változatos, és a neuroinvazivitásra utaló jelek különböző tünetegyüttesek formájában jelenhetnek meg. Irodalmi adatok is azt támasztják alá, hogy több szervet, szervrendszert is érinthet a betegség: leírtak a fertőzéshez asszociáltan meningoencephalitist, akut flaccid paresist és paralysist, 'polio-like' myelitist, Guillain-Barré-szindrómához hasonló demyelinisatiós kórképet [5], parkinsonizmust [39], malignus ritmuszavarhoz vezető myocarditist [40], hepatitist, pancreatitist, orchitist, chorioretinitist [5] és rhabdomyolysist is [41, $42]$.
A prognózis szempontjából kevés adat áll rendelkezésre. A teljes felépülés egyetlen bizonyított prediktív faktora a 65 év alatti életkor [43]. WNND-re hajlamosít az idősebb kor, a férfinem, a hypertonia és a diabetes mellitus is [44]. Rosszabb hosszú távú kimenetelt, nagyobb halálozási arányt a 65 év feletti korosztálynál tapasztaltak [43]. Immunszupprimáltak, krónikus veseelégtelenségben szenvedők és hepatitis C-vírus-fertőzöttek esetében szignifikánsan nagyobb halálozási arányt írtak le [45]. Ezen adatokkal egybehangzóan eseteink is azt mutatták, hogy WNV-fertőzött betegeink idősebbek voltak, valamint számos alap- és társbetegségben szenvedtek. A legidősebb beteg halálához a WNV-fertőzésen kívül komorbid statusa is hozzájárulhatott.

A WNV-fertőzés laboratóriumi diagnózisa szerológiai és molekuláris biológiai (PCR-) vizsgálatok alapján igazolható. A meghatározáshoz vér- (szérum és alvadásgátolt vér), liquor- és vizeletminták szükségesek. Akut fertőzés esetén vizeletmintából hosszabb ideig és nagyobb koncentrációban mutatható ki a vírus [46]. A vizeletminta PCR-vizsgálata mellett az alakos elemeket is tartalmazó alvadásgátolt, az EDTA káliumsójával kezelt vérvételi csőbe levett teljes vér PCR-vizsgálatával szintén nagy hatékonysággal mutatható ki a vírus [24]. Akut WNV-fertőzés klinikai gyanúja esetén natív és EDTA-val kezelt vérvételi csőbe levett vérminták, valamint vizeletminta beküldése szükséges a vizsgálólaboratóriumba (Virális Zoonózisok Nemzeti Referencia Laboratóriuma, Budapest). Amennyiben más okból kifolyólag levételre kerül, liquor cerebrospinalis minta is küldhető ellenanyag-vizsgálat elvégzéséhez.

A betegség kezelése szupportív, fájdalomcsillapítást, szekunder infekciók kezelését foglalja magában [3], a WNND-k kapcsán kialakuló légzési elégtelenség, epileptiform görcsök pedig intenzív osztályos kezelést indokolnak. Több terápiás próbálkozást dokumentáltak gamma-immunglobulin, WNV-specifikus monoklonális antitestek, kortikoszteroidok, ribavirin, interferon-alfa2 b alkalmazásáról, a hatékonyság azonban egyik esetben sem volt egyértelmúen bizonyítható [3]. Ennek megfelelően betegeinknél is szupportív terápia történt NSAID, mannitol, szteroid alkalmazásával, szekunder infekciók kezelésével, valamint az adott belgyógyászati alapbetegségek ellátásával.

A potenciálisan súlyos szövődményekkel járó nyugatnílusi encephalitis (WNE) prevenciója ezért - elsősorban az endémiás területeken - kiemelten fontos. Lovak esetében Magyarországon is elérhető vakcina a megelőzésre, mely egy inaktivált WNV-törzset tartalmaz. Humán oltóanyag egyelőre nem áll rendelkezésre, azonban több klinikai kutatás is folyik, fázis I. vizsgálati szakaszba lépett egy hidrogén-peroxiddal inaktivált vírusvakcina fejlesztése is [47].

Jelenleg a humán populációban a WNV-fertőzés prevenciója a vírust hordozó szúnyog csípésének elkerülésében merül ki, mely fóleg a vulnerábilis betegcsoportokban (idősek, immunszupprimáltak) esszenciális. 
Ezzel kapcsolatos tanácsok a lakosság számára elérhetők az európai (ECDC) [48] és az egyesült államokbeli (Centers for Disease Control and Prevention, CDC) [49] járványügyi szerv honlapjáról, valamint magyar nyelvű tájékoztató az Állami Népegészségügyi és Tisztiorvosi Szolgálat (ÁNTSZ) weboldalán [50].

A lakosság körében fontos a prevenció. A szúnyogcsípés megelőzésére tett egyéni óvintézkedések mellett a szúnyogtenyésző helyek számának gyérítésével lehet csökkenti a vírusvektorok számát.

Bár a WNV-fertőzés továbbra is viszonylag ritka hazánkban az endémiás területekhez képest, a fertőzés gyakoriságának ugrásszerû növekedése miatt egyre gyakrabban szükséges felismerni és kezelni ezt az eddig kevéssé ismert betegséget. A kórkép a diverzitása miatt gyakran okoz differenciáldiagnosztikai problémát az ellátóknak, pedig az időben megkezdett szupportív terápia elősegítheti a kórlefolyás jó prognózisát. Szerencsére kicsi a magas mortalitású szövődményhez vezető infekció, például az encephalitis kialakulásának valószínúsége, de az ismeretlen etiológiájú neurológiai kórképeknél - különösen encephalitisre utaló tünettan esetén - fontos gondolni a WNV-fertőzésre.

Anyagi támogatás: A közlemény megírása, illetve az alapját képező és a kapcsolódó kutatómunka anyagi támogatásban nem részesült.

Szerzői munkamegosztás: K. M.: Az irodalmi háttér feldolgozása, statisztikai elemzés, értékelés, a kézirat, ábrák, táblázatok elkészítése. L. Zs.: Irodalomkutatás, a kézirat végső szövegének kialakítása. N. A.: A nyugatnílusi vírus laboratóriumi diagnosztikai vizsgálatai. N. F.: A kézirat elkészítésének szakmai ellenőrzése. P. É.: A kézirat szövegezésének kritikai olvasata, korrekciós javaslatok. S. V.: Adatfeldolgozás. T. K. M.: Az adatok elemzése. V. Cs.: A közlemény alapötlete, az elemzés megtervezése, a kézirat megszövegezése. Az ábrák kivétel nélkül a kutatás keretében készült saját ábrák. A közlemény végleges változatát valamennyi szerző elolvasta és jóváhagyta. A cikk nem sérti a helsinki deklaráció előírásait. Kéziratunk humánvizsgálatai az illetékes etikai bizottság jóváhagyásával történtek.

Érdekeltségek: A szerzőknek nincsenek érdekeltségeik.

\section{Irodalom}

[1] European Centre for Disease Prevention and Control. Unusual early start of the West Nile fever season and rise in cases: ECDC assessment. ECDC, Stockholm, 2018. Available from: https:// ecdc.europa.eu/en/news-events/unusual-early-start-west-nilefever-season-and-rise-cases-ecdc-assessment [accessed: May 5, 2019].

[2] Paz S. Climate change impacts on West Nile virus transmission in a global context. Philos Trans R Soc Lond B Biol Sci. 2015; 370: 20130561 .
[3] Petersen LR, Brault AC, Nasci RS. West Nile virus: review of the literature. JAMA 2013; 310: 308-315.

[4] Smithburn KC, Hughes TP, Burke AW, et al. A neurotropic virus isolated from the blood of a native of Uganda. Am J Trop Med Hyg. 1940; 20: 471-492.

[5] Hayes EB, Sejvar JJ, Zaki SR, et al. Virology, pathology, and clinical manifestations of West Nile virus disease. Emerg Infect Dis. 2005; 11: 1174-1179.

[6] Colpitts TM, Conway MJ, Montgomery RR, et al. West Nile virus: biology, transmission, and human infection. Clin Microbiol Rev. 2012; 25: 635-648.

[7] Alpert S, Fergerson J, Noël L. Intrauterine West Nile virus: ocular and systemic findings. Am J Ophthalmol. 2003; 136: 733735.

[8] Yango AF, Fischbach BV, Levy M, et al. West Nile virus infection in kidney and pancreas transplant recipients in the Dallas-Fort Worth Metroplex during the 2012 Texas epidemic. Transplantation 2014; 97: 953-957.

[9] Domanović D, Gossner CM, Lieshout-Krikke R, et al. West Nile and Usutu virus infections and challenges to blood safety in the European Union. Emerg Infect Dis. 2019; 25: 1050-1057.

[10] Pealer LN, Marfin AA, Petersen LR, et al. Transmission of West Nile virus through blood transfusion in the United States in 2002. N Engl J Med. 2003; 349: 1236-1245

[11] European Centre for Disease Prevention and Control. West Nile fever. In: ECDC. Annual epidemiological report for 2015. ECDC, Stockholm, 2017. Available from: https://ecdc.europa. $\mathrm{eu} /$ sites/portal/files/documents/AER_for_2015-West-Nilefever.pdf [accessed: May 5, 2019].

[12] Burki T. Increase of West Nile virus cases in Europe for 2018. Lancet 2018; 392: 1000

[13] Pervanidou D, Detsis M, Danis K, et al. West Nile virus outbreak in humans, Greece, 2012: third consecutive year of local transmission. Euro Surveill. 2014; 19: 20758.

[14] Ludlow M, Kortekaas J, Herden C, et al. Neurotropic virus infections as the cause of immediate and delayed neuropathology. Acta Neuropathol. 2016; 131: 159-184.

[15] Fall G, Di Paola N, Faye M, et al. Biological and phylogenetic characteristics of West African lineages of West Nile virus. PLoS Negl Trop Dis. 2017; 11: e0006078.

[16] Kuczmog Z. Examination of virulence markers of West Nile virus. [A nyugat-nílusi vírus virulencia markereinek vizsgálata.] Thesis. Budapest, 2014. [Hungarian]

[17] Bakonyi T, Ivanics E, Erdélyi K, et al. Lineage 1 and 2 strains of encephalitic West Nile virus, Central Europe. Emerg Infect Dis. 2006; 12: 618-623.

[18] Kutasi O, Bakonyi T, Lecollinet S, et al. Equine encephalomyelitis outbreak caused by a genetic lineage 2 West Nile virus in Hungary. J Vet Intern Med. 2011; 25: 586-591.

[19] Venter M, Human S, Zaayman D, et al. Lineage 2 West Nile virus as cause of fatal neurologic disease in horses, South Africa. Emerg Infect Dis. 2009; 15: 877-884.

[20] Bakonyi T, Ferenczi E, Erdélyi K, et al. Explosive spread of a neuroinvasive lineage 2 West Nile virus in Central Europe, 2008/2009. Vet Microbiol. 2013; 165: 61-70.

[21] Infectious disease weekly report. [Fertőző betegségek heti adatai.] Available from: https://www.antsz.hu/felso_menu/temaink/jarvany/Fertozo_betegsegek/fertozo [accessed: July 1, 2019]. [Hungarian]

[22] European Centre for Disease Prevention and Control. Epidemiological update: West Nile virus transmission season in Europe, 2018. ECDC, Stockholm, 2018. Available from: https://ecdc. europa.eu/en/news-events/epidemiological-update-west-nilevirus-transmission-season-europe-2018 [accessed: May 5, 2019].

[23] Barzon L, Pacenti M, Franchin E, et al. Excretion of West Nile virus in urine during acute infection. J Infect Dis. 2013; 208: 1086-1092. 
[24] Lustig Y, Mannasse B, Koren R, et al. Superiority of West Nile virus RNA detection in whole blood for diagnosis of acute infection. J Clin Microbiol. 2016; 54: 2294-2297.

[25] Nagy A, Mezei E, Nagy O, et al. Extraordinary increase in West Nile virus cases and first confirmed human Usutu virus infection in Hungary, 2018. Euro Surveill. 2019; 24: 1900038.

[26] Rios M, Daniel S, Chancey C, et al. West Nile virus adheres to human red blood cells in whole blood. Clin Infect Dis. 2007; 45: 181-186.

[27] Linke S, Ellerbrok H, Niedrig M, et al. Detection of West Nile virus lineages 1 and 2 by real-time PCR. J Virol Methods 2007; 146: 355-358.

[28] Nikolay B, Weidmann M, Dupressoir A, et al. Development of a Usutu virus specific real-time reverse transcription PCR assay based on sequenced strains from Africa and Europe. J Virol Methods 2014; 197: 51-54.

[29] Calisher CH, Karabatsos N, Dalrymple JM, et al. Antigenic relationships between flaviviruses as determined by cross-neutralization tests with polyclonal antisera. J Gen Virol. 1989; 70: 37-43.

[30] Chaskopoulou A, Dovas C, Chaintoutis S, et al. Evidence of enzootic circulation of West Nile virus (Nea Santa-Greece-2010, lineage 2), Greece, May to July 2011. Euro Surveill. 2011; 16: 19933.

[31] European Commission. Commission Implementing Decision 2012/506/EU of 8 August 2012 amending Decision $2002 / 253$ /EC laying down case definitions for reporting communicable diseases to the Community network under Decision No 2119/98/EC of the European Parliament and of the Council (notified under document $\mathrm{C}(2012) 5538$ ). Publication Office of the European Union, Luxembourg, 2012.

[32] Herweh C, Ringleb PA, Rauch G, et al. Performance of e-ASPECTS software in comparison to that of stroke physicians on assessing CT scans of acute ischemic stroke patients. Int J Stroke 2016; 11: 438-445.

[33] Sejvar JJ. West nile virus: an historical overview. Ochsner J. 2003; 5: 6-10.

[34] Savuła Gh, Ludu L, Aniłă A, et al. West Nile virus infections in Romania - past, present and perspective. Lucrări Ştiinţifice Medicină Veterinară 2008; 41: 301-308.

[35] Han LL, Popovici F, Alexander JP Jr, et al. Risk factors for West Nile virus infection and meningoencephalitis, Romania, 1996. J Infect Dis. 1999; 179: 230-233.

[36] Centers for Disease Control and Prevention. Provisional surveillance summary of the West Nile virus epidemic - United States, January-November 2002. MMWR Morb Mortal Wkly Rep. 2002; 51: 1129-1133.

[37] Barzon L, Pacenti M, Franchin E, et al. Large human outbreak of West Nile virus infection in north-eastern Italy in 2012. Viruses $2013 ; 5$ : 2825-2839.
[38] Rizzo C, Napoli C, Venturi G, et al. West Nile virus transmission: results from the integrated surveillance system in Italy, 2008 to 2015. Euro Surveill. 2016; 21: 30340.

[39] Sejvar JJ, Haddad MB, Tierney BC, et al. Neurologic manifestations and outcome of West Nile virus infection. JAMA 2003; 290: 511-515.

[40] Kushawaha A, Jadonath S, Mobarakai N. West Nile virus myocarditis causing a fatal arrhythmia: a case report. Cases J. 2009; 2: 7147.

[41] Burden Z, Fasen M, Judkins BL, et al. A case of West Nile virus encephalitis accompanied by diabetic ketoacidosis and rhabdomyolysis. IDCases 2019; 15: e00505.

[42] Medarov BI, Multz AS, Brown W, et al. West Nile meningoencephalitis and rhabdomyolysis. Lancet Infect Dis. 2005; 5: 2 .

[43] Klee AL, Maidin B, Edwin B, et al. Long-term prognosis for clinical West Nile virus infection. Emerg Infect Dis. 2004; 10: $1405-1411$.

[44] Jean CM, Honarmand S, Louie JK, et al. Risk factors for West Nile virus neuroinvasive disease, California, 2005. Emerg Infect Dis. 2007; 13: 1918-1920.

[45] Murray K, Baraniuk S, Resnick M, et al. Risk factors for encephalitis and death from West Nile virus infection. Epidemiol Infect. 2006; 134: 1325-1332.

[46] Nagy A, Nagy O, Bán E, et al. Detection of West Nile virus in human samples: follow-up studies during the 2015 seasonal period. [A nyugat-nílusi vírus kimutatása humán betegmintákból: nyomon követéses vizsgálatok a 2015. évi szezonális időszakban.] Orv Hetil. 2017; 158: 791-796. [Hungarian]

[47] Poore EA, Slifka DK, Raué HP, et al. Pre-clinical development of a hydrogen peroxide-inactivated West Nile virus vaccine. Vaccine 2016; 35(2): 283-292.

[48] European Centre for Disease Prevention and Control. Prevention and control measures for West Nile fever. ECDC, Stockholm. Available from: https://ecdc.europa.eu/en/west-nile-fever/prevention-and-control [accessed: June 14, 2019].

[49] Centers for Disease Control and Prevention. West Nile virus prevention. CDC, Atlanta, GA. Available from: https://www.cdc. gov/westnile/prevention/index.html [accessed: June 14, 2019].

[50] General information about mosquito bites. Prevent mosquito bites. [Tájékoztató a szúnyogok elleni védekezésről. Felhívás a szúnyogok elleni védekezésre.] Available from: https://www. antsz.hu/felso_menu/temaink/jarvany/WN_lakossagi_tajekoztato [accessed: July 1, 2019]. [Hungarian]

(Varga Csaba dr., Kaposvár, Tallián Gyula u. 20-32., 7400 e-mail: vcspaper@gmail.com) 